\title{
Wartość i jakość życia w ujęciu transdyscyplinarnym, red. J. Bartoszek, Biblos, Tarnów 2015, ss. 318.
}

Wartość i jakość życia to podstawowe aspekty ludzkiej egzystencji. Człowiek bowiem w okresie swojego bytowania kieruje się wartościami, które przyjmuje obligatoryjnie. W dużej mierze zależą one od subiektywnego i obiektywnego życia jednostki. Subiektywny wymiar stanowi ich hierarchię, w której jednostka plasuje wartości na szczeblu drabiny hierarchicznej zgodnie z wyznawanym kanonem postępowania, zachowania oraz moralnością, a nawet kulturą. W sensie obiektywnym istnieją niezależnie od podmiotu, który je wyznaje, są powszechnie obowiązujące, w jakiejś mierze niezależne od woli oraz świadomości jednostki. Wartości te należy uznać za powszechnie istniejące, którymi człowiek się kieruje, realizuje je, chociaż nie mają większego wpływu na jego doskonałość życia.

Dlatego też przez wartości najczęściej rozumie się „ogólne i trwałe orientacje, określające perspektywy życia codziennego (w tym jego jakości), jego znaczenie i sens, a także jako wyznaczniki norm odnoszących się do konkretnych zachowań"’. W katolickiej nauce społecznej, człowieka określa się jako wartość najwyższą z przynależącymi mu prawami i godnością. Właśnie godność jako wartość każdej osoby ludzkiej przejawia się w elementarnych prawach człowieka. W jej perspektywie człowiek jawi się jako istota autoteliczna, o niezbywalnych prawach. Jest to ujęcie normatywne (filozoficzne), związane z szacunkiem dla samego siebie i dla innych ${ }^{2}$. Godność ludzka to po prostu sama osoba jako wartość [...] ta wartość sama w sobie stanowi podstawę - $\mathrm{i}$ to uniwersalną życia człowieka³

Istnieje cała gama wartości: biologiczne, bazujące na doznawaniu przyjemności i zaspokajaniu potrzeb; ekonomiczne, wynikające z użyteczności; estetyczne, obejmujące sferę przeżyć związanych z pięknem; społeczne, odzwierciedlające interesy grupy lub społeczeństwa; religijne, mające związek z sacrum oraz etyczne, składające się z wartości moralnych i duchowych. Świat wartości stanowi zatem

1 J. Mariański, W. Zdaniewicz, Wartości religijne i moralne młodzieży polskiej, „Studia Socjologiczno-Religijne" 1991 nr 13, s. 14.

2 J. Kozielecki. O człowieku wielowymiarowym. Eseje psychologiczne. Warszawa 1988, s. 174.

3 A. Rodziński. Osoba, moralność, kultura. Lublin 1989 s. 32. 
istotny wymiar każdego człowieka. Człowiek potrzebuje takich wartości, jakie byłyby dla niego satysfakcjonujące. $Z$ całego zaś świata wartości wybiera te, które mają dla niego największe znaczenie. W tym aspekcie można mówić o jakości życia człowieka. Dobrym przykładem wydaje się być pogląd T. Parsonsa, według którego wartości są nieodłącznym elementem kultury danego społeczeństwa i człowieka w nim funkcjonującego. Zwarzywszy na człowieka należy zawsze ujmować to w analizie personalistycznej, bowiem tylko wówczas można mówić o jakości jego życia. Ujęcie przedmiotowe z natury wyklucza osobę, jako podmiot i ukazuje instrumentalną stronę jej funkcjonowania. W tym zakresie warto przypomnieć, iż człowieka „nie podobna traktować jako koncepcji czy idei, lecz owa podmiotowość każe pochylić się z troską nad każdym konkretnym człowiekiem", jego jakością i aksjologią życia.

Szczególnie wartość życia pozostaje najcenniejszym darem każdego człowieka. Ponieważ życie należy do wartości fundamentalnej, dlatego jest nienaruszalnym prawem każdego człowieka. Prawa tego nie powinno się znosić ani też zmieniaćs. Tym bardziej, że pozostaje ono również fundamentem każdego społeczeństwa. Do tego celu Bóg powołał mężczyznę i kobietę, którzy zawierając małżeństwo wyznaczają sobie dwa podstawowe cele: zrodzenia i wychowania dzieci.

Pojęcie jakości życia nie wydaje się być zagadnieniem prostym i łatwym. Cechuje go nie tylko wieloznaczność terminologiczna, ale też podejście interdyscyplinarne: teologia, psychologia, pedagogika, socjologia, ekonomia, polityka, medycyna... Warto jednak dodać, że termin jakość życia dopiero ,ze względu na zainteresowanie wartościami odnoszącymi się do Frommowskiego „być” zamiast „mieć" został rozszerzony na nowe obszary ludzkiego funkcjonowania", co nie oznacza, że w kontekście aksjologicznym nie był używany. Kryterium określania, jakości życia zawsze będzie zależało od subiektywnych i obiektywnych wymiarów ludzkiej egzystencji. Niewątpliwie jakość życia dotyczy dwóch ważnych aspektów ludzkiego bytowania: służby życiu i świętości życia.

Problematyka wartości i jakości życia stała się przedmiotem badawczym monografii pt. Wartość i jakość źycia w ujęciu transdyscyplinarnym (monografia dwujęzyczna), napisanej pod redakcja naukową Jana Bartoszka. Monografia składa się z dwóch rozdziałów (I- Troska o życie inspirowane Evangelium vitae; II - Kondycja

4 J. Mazur, Duch pracy socjalnej w kontekście pytania o człowieka, w: Współczesne wyzwania pracy socjalnej, red., W. Szymczak, Lublin 2009, s. 14.

5 J. Bajda, Aspekt prawny, w: Stownik matżeństwa i rodziny red. E. Ozorowski, Warszawa - Łomianki 1999, s. 352.

6 M. Wnuk, J. T. Marcinkowski, Jakość życia jako pojęcie pluralistyczne o charakterze interdyscyplinarnym, „Probl Hig Epidemiol” 2012 nr 93 (1), s. 23. 
życia ludzkiego i jego promocja we współczesnych uwarunkowaniach). Rozdziały te zostały poprzedzone przesłaniem Ks. abp. Zygmunta Zimowskiego oraz słowem biskupa tarnowskiego Andrzeja Jeża. Całość monografii spięta została klamrą homilii biskupa tarnowskiego Andrzeja Jeża wygłoszona w uroczystość Zwiastowania Pańskiego, obchodzonej jako dzień świętości życia.

$\mathrm{W}$ rozdziale pierwszym - Troska o życie inspirowane Evangelium vitae zawarto cztery artykuły. Pierwszy z nich pt. Zagadnienie „,wartości i ,jakości życia ludzkiego w encyklice Evangelium vitae, w którym opisano biblijne źródła wartości i jakości życia; życie, jako fundamentalna wartość, integralna koncepcja ,jakości życia”. Artykuł drugi podejmuje tematykę dotyczącą głównej linii antropologiczno-moralnej w przesłaniu Evangelium vitae. Autor już na początku artykułu słusznie zaznacza: ,przypomnijmy, że od prawie stu pięćdziesięciu lat żyjemy w czasach szczególnego starcia pomiędzy „kulturą życia” i „kulturą śmierci”. W dalszej jego części ukazuje treści dotyczące kontekstów odczytywania Evangelium vitae, zasady i linie argumentacyjne omawianej tematyki (personalistyczną, prawno-antropologiczną, etyczną i kulturową), mentalność Kainową, postawy nieprzychylne wobec dziecka, antykoncepcję - czyli jak zaznacza autor tekstu, wojnę o „nieodpowiedzialność seksualną”. In vitro - człowiek bez ojca, bez matki, bezdomny i eksperymenty na dziecku dotykając inżynierii społecznej i genetycznej. Artykuł został zakończony modlitwą Jana Pawła II za rodziny. Kolejny artykuł autorstwa J. Wróbla pt. Matżeństwo i rodzina miejscem szczególnej troski o ludzkie życie w świetle „,Karty Praw rodziny” $i$,Evangelium vitae”, analizuje teologiczne i eklezjalne przesłanie na temat prawa człowieka do życia, eklezjalne kanony opieki zdrowotnej człowieka, w których podkreślono antropologiczny fundament troski o życie. Następnie autor uwypukla problemy bioetyczne w kontekście obowiązków i praw rodziców. Opisane dokumenty stanowią ważny element pochylenia się nad małżeństwem i rodziną, szczególnie w kontekście ówczesnych i współczesnych czasów. Ostatni artykuł I. Stolarczyka „Evangelium vitae” inspiracja odnowy społeczeństwa przez budowanie dobra wspólnego podejmuje analizę aksjologicznego świata egzystencji ludzkiej w kontekście społecznych uwarunkowań w oparciu o wskazany dokument papieski. Stąd też autor podejmuje treści dotyczące troski o odnowę życia społecznego, polityczną odnowę życia społecznego poprzez roztropną troskę o dobro wspólne oraz powinność chrześcijan wobec polityki. Ponadto stwierdza, że „ nie może mieć solidnych podstaw społeczeństwo, które - choć opowiada się za wartościami takimi jak godność osoby, sprawiedliwość i pokój - zaprzecza radykalnie samemu sobie, przyjmując i tolerując najrozmaitsze formy ponizania i zaruszania życia ludzkiego" (s. 147).

Drugi rozdział niniejszej monografii zatytułowany - Kondycja życia ludzkiego i jego promocja we współczesnych uwarunkowaniach - odsłania kolejne pięć 
artykułów. W pierwszym pt. Jakość życia, a wybrane obszary społecznego upośledzenia młodzieży w nowoczesnym społeczeństwie, podjęto analizę dotyczącą wybranych aspektów rozumienia pojęcia ,jakość życia”. Zwrócono też uwagę na czynnik bezrobocia, jako znaczącego obszaru upośledzenia jakości życia w wymiarze jednostkowym i społecznym oraz wartościowanie jako aspekt jakości życia młodych osób bezrobotnych - ilustracje empiryczne w regionie Zamojskim. W kolejnym artykule podjęto tematykę Stużba życiu - odwaga w obronie życia i jej konsekwencje. Autor B. Chazan stwierdził, że „powinniśmy bronić każdego życia, szanować je, kochać i mu służyć"(s. 209). Ponadto autor ukazał współczesną sytuację dotyczącą walki ze środowiskami liberalnymi w zakresie obrony życia i podkreślił, iż „trwa na świecie odbieranie złu znamion zła. Zostało ono kulturowo oswojone" (s. 214) . W obszarze obrony życia prezentuje się również trzeci artykuł pt. Konsekwencje przestępstwa aborcji w Kościele rzymskokatolickim, w którym autor analizuje dramat aborcji w nauczaniu Jana Pawła II, przestępstwo aborcji w Kodeksie Prawa Kanonicznego z 1983 roku, dotyka zagadnienia ekskomuniki latae sententiae - czyli kto ma prawo do zniesienia kary za dokonanie aborcji, oraz pastoralnych wskazówek dotyczących zadośćuczynienia i możliwości powrotu do pełnej wspólnoty z Kościołem katolickim. Troska o życie w doświadczeniu niepełnosprawności i cierpienia to kolejny artykuł odsłaniający wartość każdego ludzkiego życia oraz wartość osoby z doświadczeniem niepełnosprawności w wymiarze przyrodzonym i nadprzyrodzonym. Nadto autor uwrażliwia czytelnika, podkreślając rolę rodziny i jej troskę o życie osoby doświadczonej niepełnosprawnością i wartość tych osób dla społeczeństwa. Niewątpliwie osoby z doświadczeniem niepełnosprawności nie mogą być marginalizowane ani wykluczane z przestrzeni społecznej. Pozostają bowiem cennym darem jego funkcjonowania, nawet w wymiarze ich cierpienia. Ostatni artykuł drugiego rozdziału Kryzys życia. Psychospołeczne aspekty samobójstwa dotyczy kryzysu życia w aspekcie problemów suicydalnych. Autor ukazał zagadnienie suicydalności w wymiarze społecznym, grupy ryzyka zachowań suicydalnych, cechy wspólne towarzyszące tego rodzaju czynom, mity na temat zachowań samobójczych oraz role pomocy i profilaktyki. Istotnym aspektem artykułu wydaje się być konkluzja, w której podkreślił, że „pragnienie życia powinno być zawsze podstawową tęsknotą każdego człowieka" (s. 290).

Niewątpliwie prezentowana publikacja jest cenna i wartościowa, podkreśla bowiem jeden z najistotniejszych aspektów egzystencji człowieka, czyli wartość i jakość jego życia. I chociaż cechą charakterystyczną nowoczesnych państw demokratycznych jest relatywne podejście do obrony życia, to jednak z samej swej natury życie jest najwyższym dobrem człowieka i społeczeństwa. W myśl społecznego nauczania życie w rzeczywistości ludzkiej, etycznej, moralnej i religijnej 
a nie tylko biologicznej pozostaje najcenniejszą wartością. Tak też rozumiane jest darem Boga od poczęcia do naturalnej śmierci i stanowi podstawową wartość dla osoby, a także społeczności państwowej.

W tym miejscu należy podkreślić, iż redaktor niniejszej monografii podejmuje tematykę interesującą, aktualne ważną i jakościowo istotną nie tyko w sferze dociekań naukowych, ale także społecznych. Obok tematu życia: zrodzenia, kształtowania, troski o nie, aksjologii w ujęciu interdyscyplinarnym nie można przejść obojętnie. Szczególnie gdy bierze się pod uwagę analizę tak ważnego dokumentu jakim jest Encyklika Evangelium vitae Jana Pawła II. Jest to zatem dzieło interesujące, aktualne, ważne naukowo, a jego nowatorskość mieści się w zakresie troski o człowieka i rodzinę.

Czytelnik wczytujący się w meandry tekstów ukazujących wartość i jakość życia, z ciekawością będzie sięgał po kolejny artykuł niniejszej publikacji chcąc uchwycić integralny obraz wartości życia oraz praktyczne wskazania w konfrontacji z sytuacjami, jakie pojawiają się na rynku społeczeństw globalnych. Współcześnie w demokratycznych państwach ciągle trwa batalia o życie. Oznacza to, że ciągła walka o życie, jego obrona i troska stanowi wielkie wyzwanie dla współczesnego świata, zaś dokonujące się przemiany polityczno - społeczno gospodarczo - kulturowe nie dzieją się w odrębności, ale dotykają tej fundamentalnej wartości, jaką jest życie. W tym aspekcie zamysł redaktora publikacji jest istotnym walorem budowania przestrzeni budzenia świadomości ludzi różnych środowisk społecznych w perspektywie szacunku, obrony i troski o życie. Sam bowiem zapisał, że publikacja znajdzie swojego adresata wśród ,pracowników służby zdrowia i poradni rodzinnych: ruchów i stowarzyszeń katolickich a także wszystkich, którym leży na sercu ochrona i promocja życia" (s. 110).

Kolejnym walorem opracowania jest teoretyczne ujęcie wartości i jakości życia $\mathrm{w}$ aspekcie interdyscyplinarnym oraz połączenie go z praktycznymi obszarami lokującymi się w przestrzeni społecznej, w szczególności badaniami dotyczącymi bezrobocia osób z doświadczeniem niepełnosprawności i istotnych statystyk w obszarze suicydalności. Stąd też pojawiło się podzielnie monografii na dwa rozdziały, chociaż wydaje się, że w sensie metodologicznym zasadnym byłoby podzielnie publikacji na dwie części, a nie rozdziały, co jednak nie umniejsza waloru prezentowanej publikacji. Osobliwym wydaje się także ujęcie tematu niniejszego opracowanie w aspekcie transdyscyplinarności na rzecz ujęcia interdyscyplinarnego z podkreśleniem refleksji naukowej w oparciu o encyklikę Evangelium vitae.

Cennym dodatkiem publikacji są: przesłanie ks. abpa Zygmunta Zimowskiego wskazującego na trzy imperatywy: broń życia, miłuj życie, służ życiu oraz słowa ks. bpa Andrzeja Jeża podkreślającego, że misją kościoła jest uwrażliwianie 
sumień, bowiem żyjemy w czasach, w których człowiek nie umie mówić „tak” ani życiu, ani śmierci (s. 26).

Analiza ludzkiej rzeczywistości dotyczącej wartości i jakości życia w wymiarze jednostkowym i społecznym wymaga od osoby podejmującej się tego zagadnienia erudycji, ale też pokory. Życie jest święte i aksjologicznie najistotniejsze. Potrzebna jest kompetencja, aby odbiorcy naszkicować specyfikę złożonego i tajemniczego świata Boga i człowieka. W tym aspekcie prezentowana publikacja jest cenna i wartościowa oraz stanowi istotny aspekt świata duchowego i społecznego człowieka, małżeństwa i rodziny.

Ks. Józef Młyński

Wydziat Studiów nad Rodzina UKSW w Warszawie 